\title{
Analysis of relationship between salinity and top-dying diseases of Sundri trees in Sundarbans, Bangladesh
}

\author{
Awal, Mohd. Abdul \\ Environmental Scientist (Ministry of Environment and Forest); Founder \& Chief Advisor, Health \& Pollution Research Farm, 23-09-37 \\ Avenue, Apt, No: 1, Long Island City, New York, USA
}

Email address:

abdul_awal2004@yahoo.com

To cite this article:

Awal, Mohd. Abdul. Analysis of Relationship between Salinity and Top-Dying Diseases of Sundri Trees in Sundarbans, Bangladesh. Science Journal of Analytical Chemistry. Vol. 2, No. 4, 2014, pp. 29-40. doi: 10.11648/j.sjac.20140204.11

\begin{abstract}
At the advent of British rule in 1765, the Sundarbans forests were double their present size (Seidensticker, and Hai, 1983; Khan, 1997). Sundarbans mangroves in Asia including Bangladesh, India, and East Africa previously contained a much fuller range of species (Seidensticker, and Hai, 1983; Khan, 1997). In the Southeast Asian region, species diversity of mangroves was previously much higher (Ellison, 1998, 2000). Although, a particular class of men made a profession of collection of wood, fish, Golpata, Goran, natural beauty, oil, honey, and wax in Sundarbans (Awal, 2007), but it is facing tremendous problems (Awal, 207, 2009, 2014). But, it is now under serious threatened through human destruction, and by ecological pollution (Awal, 2007). The cause of this dieback is still not well understood unknown. The present work has investigated one of the possible factors that might be causing this top-dying, namely the concentrations of various chemical elements present in the sediments, particularly Salinity $(\mathrm{Na})$, Exchangeable $\mathrm{K}$, heavy metals, though other chemical parameters such as the $\mathrm{pH}$, salinity, moisture content of the sediment and nutrient status were also assessed. (Awal, 2007). $\mathrm{Na}$ has no relationship with the amount of top-dying of Sundri trees in Sundarbans. However, a serious killer disease (top dying) of $H$. fomes in Sundarbans is affecting millions of the trees (Awal, 2007). The loss of $H$. fomes will have a major impact on the Sundarbans mangrove ecosystem, as well as lead to economic losses. A questionnaire survey was conducted among different groups of people inside and outside of Sundarbans to explore local perceptions as to the possible causes of top dying. This confirmed the increase in top-dying prevalence (Awal, 2007). Most of the elements including Salinity of soil and water studied had no significant correlation with the top dying of Heritiera fomes. However, Sn, Exchangeable K, and soil $\mathrm{pH}$ were significantly related, and three elements, namely $\mathrm{Pb}, \mathrm{Zn}, \mathrm{Ni}$, were also close to significance. Sn concentration is negatively associated with top dying. Soil $\mathrm{pH}$ varied significantly in the different plots. Exchangeable $\mathrm{K}$ was positively associated with the tree diameter whether the top dying was severe or mild.
\end{abstract}

Keywords: Salinity Intrusion, Chemical Contamination, Causal Factors, Heavy Metal Concentrations, Chemical Contamination, Pollution, Sundarbans, Top-Dying

\section{Introduction}

The Sundarbans is the largest single mangrove forest in the world, occupying about $6,029 \mathrm{~km}^{2}$ in Bangladesh and the rest in India (Iftekhar \& Islam, 2004). Numerous authors have discussed the influences of tidal flooding and salinity on the distribution and zonation of mangrove vegetation (Chapman, 1977). There are distinctive plant / animal relationships existing in tidal marshes (Daiber, 1974). Salt-marsh formations in tropical latitudes are usually limited in extent because of competition with mangrove species (Chapman, 1960; Davies, 1940, 1966). In the mud flats and lower salt marshes the soil salinity is closely related to that of the flooding water bodies (Beeftink, 1965, 1966). A general survey on soil and water salinity was aimed at re-delineating the boundary of salinity zones of the Sundarban suggested by Curtis in 1933. The results indicated that soil salinity increased slightly from east to west and from north to south. Salinity variation showed a seasonal cycle, where soil salinity remained between 2000 and 4500 micro mohs in most parts of the Sundarbans during March to May (Anon, 1972). Karim, 1988; and Bhuiyan, 1994 reported that salinity concentration in the eastern part of the Sundarbans is the 
lowest and that concentration of salinity in the western part is the highest, but moderate salinity concentration is found in the central part of the Sundarbans. Karim, 1988 recorded and measured salinity of eastern, central and western Sundarbans and has shown that mean salinity from these mentioned zones were 6.29, 8.03, and $12.98 \mathrm{ppt}$ respectively. Bangladesh Forest Research Institute (BFRI), during 1990 to 1994 , conducted mean monthly soil salinity sampling among the compartments 28 (Chandpai), 36 (Kassiabad), and 46 (Burigoalini), and recorded 3168.44, 4590.15, and 6579.79 micro mhos respectively.

McMillan (1975) observed that the effect of salt on mangroves reduces as the clay content in the soil increases. It is observed that salinity tends to zonal and seasonal variations of soil and water in the Sundarban, and there are prominent but inconsistent variations from year to year and season to season (Chaffey, et al., 1985; Hassan, et al., 1990). For the less brackish zone of the Sundarban (Bogi station areas), the mean soil salinity was recorded as 2 micro $\mathrm{mhos} / \mathrm{cm}$, and in the moderate to highly saline zone, the mean soil salinity was recorded as 6 micro mhos $/ \mathrm{cm}$ (Paul, 2003). Seasonal variation in soil salinity between peak (April to May) and lean (September to October) periods at different locations of the Sundarban remains up to $55 \%$ to $75 \%$.

Water salinity at various places of the Sundarbans was found to be 2.5 to 3.5 times higher than that of soil salinity (Paul, 2003). Rainfall and temperature affect salinity trends of the Sundarban. Rainfall and sweet water flows from streams and rivers increase washing of excess salt from the forest floor, but dry climatic conditions accelerate evaporation rate and air temperature enhances chemical reactions. In addition, global warming and raising of sea level can affect the mangrove composition (Paul, 2003). After the dry season (March to May), the soil salinity generally remains below 2000 micro mohs in Sundarbans (Own observations staying in Sundarbans from 1993 to 1998 as head of east wildlife sanctuary, Awal, 2007). During the rainy season, fresh flows of water increase, and all rivers become full of sweet water. In addition rivers become over flooded due to sudden release of water from the Farakka barrage by India when they get overflow of sweet water, mainly from the Himalaya mountains (Lusai hill is a main source of the Ganges river's fresh water flows within the Himalaya mountains), when they divert this excess water to Bangladesh through opening all barrages including Farakka. As a result, almost every year, Bangladesh receives horrible flooding problems, terrible natural and artificial disasters. Thousands of people, assets, trees and wild-life, are losing their lives almost every year (Own observations staying in Sundarbans as head of east wildlife sanctuary, from 1993 to 1998, Awal, 2007).

It is natural to have salts present in any soil and salinity refers not to the presence of salt but rather to the presence of too much salt. Some halophyte plants can grow on soils with high salt content e.g. mangrove species particularly Ceriops decandra (Goran tree) in Sundarban. The common terrestrial plant systems are composed of "mesophytes", plants adapted to a moderate supply of water. In more saline situations, soil salt absorbed by plants may accumulate to toxic levels, leading to the death of cells and tissues; the leaf cell will die, if chloride concentrations reach toxic levels $(\mathrm{Na}>0.25-0.50 \%$ and / or chloride above $0.5-1.0 \%$ (Leece, 1984). It has been found that salinity concentration accelerates the rate of catabolism by decreasing the metabolism of Sundri (Islam, 2003), but it has not been established whether this is harmful to the tree.

\subsection{Changed Water Flow and Increased Salinity}

A wide range of arguments had been put forward concerning edaphic changes in Sundarbans. These included reduction in flow of fresh water throughout the Sundarbans because of withdrawal of water at Farakka Barrage and resultant increase in soil and water salinity (Shafi, 1982), reduction in siltation (Chowdhury, 1984), increase in siltation (Sattar, 1977), etc. These edaphic changes have been suggested to be responsible for top- dying. It may be noted that most of the suggestions were not based on experimental data, for example Banik (2000). Chowdhury (1984) stated that the reduction of fresh water discharges through the Sundarbans was due to (a) the diversion of the upstream Ganges water and (b) more use of upstream water for irrigation and industrial use. Previously the rivers of the area were very active and used to lay freshly deposited silts on top soil every year where Sundri would survive well. But with the reduction in discharge of fresh water, silt carrying capacity of the river has also been reduced. Sundri (Heritiera fomes) lacks the ability to extract fresh water from salt water at even a relatively low salt concentration (Hoffman et al., 1986). Balmforth (1985), based on the report of Chaffey et al., (1985), stated that the primary cause of Sundri top-dying was the increase in soil salinity. Withdrawal of Ganges water at Farrakka because of the dam construction in 1976 was, in his opinion, one of the possible causes for the increase in salinity in the Sundarbans. Balmforth's statement regarding the causes of Sundri top-dying due to an increase in salinity was, however, not supported by his data. Moreover, the data presented by Chaffey et al., (1985), from examined soil samples collected from 20 sites including top-dying and healthy Sundri areas in the Sundarbans, are not in agreement with Balmforth's statement, nor with the conclusion of Chaffey et al., (1985) themselves. These authors had suggested that soil salinity was higher on sites affected by top-dying than on unaffected sites, and that therefore an increase in soil salinity is an important factor in the onset of top-dying. However, severely affected topdying areas are, in fact, distributed in slightly saline to nonsaline zones as presented by Chaffey et al. (1985). Thus a total of $18 \%$ of Sundri trees with d.b.h above $5 \mathrm{~cm}$ had been affected by top-dying of Sundri in Sundarbans (Chaffey et al., 1985). Only a very small number of topdying affected Sundri were present in the salt water zone (Chaffey et al., 1985); 13-15\% in moderately salt water 
zone, $21-24 \%$ in salt water zones and $25-47 \%$ in the fresh water zone respectively. This contrast with results of Ismail (1987), who stated that soil salinity, was higher on sites affected by top-dying than on unaffected sites, suggesting that soil salinity is an important factor in the onset of topdying. Sattar (1977) inferred that mortality of Sundri is possibly due to edaphic changes such as heavy siltation, increase in salinity, less flooding by fresh water, and alteration in the frequency and duration of inundation. However, the decline of more salt tolerant species suggests that the cause of decline of the Sundri is not primarily due to insufficient fresh water flow during the dry season. Christensen (1984) stated that salinity may not be a direct cause of top-dying but is an indicator of many geochemical processes that have an impact on living organisms (e.g. by affecting nutrient availability).Hassan (1988) provided data on soil and water salinity of a number of sites in the Sundarbans. He also studied the effect of salinity of Sundri seedlings in a simulated experiment. The data on salinity was compared with those of Chaffey et al., (1985). It was observed that the top-dying did not show any consistent relationship with the salinity (Awal, 2007). Hassan (1988) reported that soil salinity in the Sundarbans varies between less than 2000 micro mhos to more than 4000 micro mhos, which rise up to about 6000 micro mohs during the lean period in April. Hassan (1988) also observed that Sundri top-dying did not show any consistent relationships with salinity (Awal, 2007). Moreover, regeneration and survival of Sundri seedlings did not show any change due to water salinity variation between the range 1,000 to 49,000 micro mhos under experimental conditions (Hassan et al., 1990). Therefore, Awal, 2007; Hassan et al., (1984) provided a detailed report on soil and salinity of the Sundarbans in relation to top-dying, regeneration and survival of Sundri, they did not observe any consistent relationships between top-dying and salinity. Regeneration and survival of Sundri seedlings also did not show any relationships to the salinity variation between 1,000 to 49,000 micro mohs under simulated conditions (Awal, 2007; Hassan, et al., 1990).

Accordingly Shell and Ross (1987) studied the $\mathrm{Na}^{+}$and $\mathrm{K}^{+}$levels in Sundri tissues and found that: (a) the $\mathrm{Na}^{+} / \mathrm{K}^{+}$ ratios in the tissues of healthy trees appear to be related to the salinity of their local environment; (b) the average percentage of $\mathrm{Na}^{+}$and $\mathrm{K}^{+}$was not significantly different in healthy and dying Sundri trees; (c) though some link was indicated between top-dying and ionic balance in plant tissue, it was not possible to resolve the causal factor and its effect. According to Lugo and Snedaker (1974), gross primary productivity of mangroves increases with the availability of fresh water. The fresh water input to the estuary is associated with physical, chemical, geological and biological melange, fauna and flora of the estuary / coastal zone. This input tends to enrich the sites (Snedaker et al., 1977). Imam (1982) noted that a system analysis and simulated studies on the ecology of mangrove forests in Florida, USA, had demonstrated that terrestrial water plays a vital role in the development of mangrove biomass, which in turn reflects the gross photosynthesis. It has been construed that both mangrove zonation and vigor are functions of nutrient availability rather than salinity alone. On the basis of the above findings Sheil and Ross (1987), concluded that these observations are compatible with a pathogenic cause of top-dying as forwarded by Rahman et al., (1983; see next section). This means that in their opinion salinity is not the causal factor for the top-dying (Awal, 2007, 2009, 2014).

More recent research on the association between salinity and top-dying of Hetiera fomes has concluded that it is not the causal factor previously thought. Awal, 2007; Hassan et al. (1990) suggested that there is no relationship between salinity and top-dying of Sundri, and data of Rahaman et al. (2003), where soil salinity was estimated in terms of the level of sodium $(\mathrm{Na})$ and electrical conductivity, revealed that there is no significant variation in the mean value of $\mathrm{Na}$ and EC in soil of the Sundarbans (Awal, 2007).

According to Gupta et al. (1986), reporting on the salt tolerance of some tree species at the seedling stage, the salinity ranges which prevail in the Sundarbans are tolerable even to some mesophytes such as Eucalyptus camaldulensis and Acacia nilotica. This observation contradicts with the inference that a species such as Sundri should be seriously affected by the salinity observed. Moreover, without a governing cause top-dying could not merely increase with time, as suggested by Awal, 2007; Chaffey et al. (1985), indicating that salinity alone can not be the cause of top-dying of Sundri.

\section{Methodology}

In this section the various field and laboratory methods used in this study will be discussed as below:

\subsection{Field Sampling Methods}

The Sundarbans Reserved Forest is located at the south west corner of the Ganges River Delta close to the Bay of Bengal, mainly on the sea-shore line, river banks, channels, and small creeks. The location of the Sundarbans within Bangladesh has been shown in Figure 1.0. 


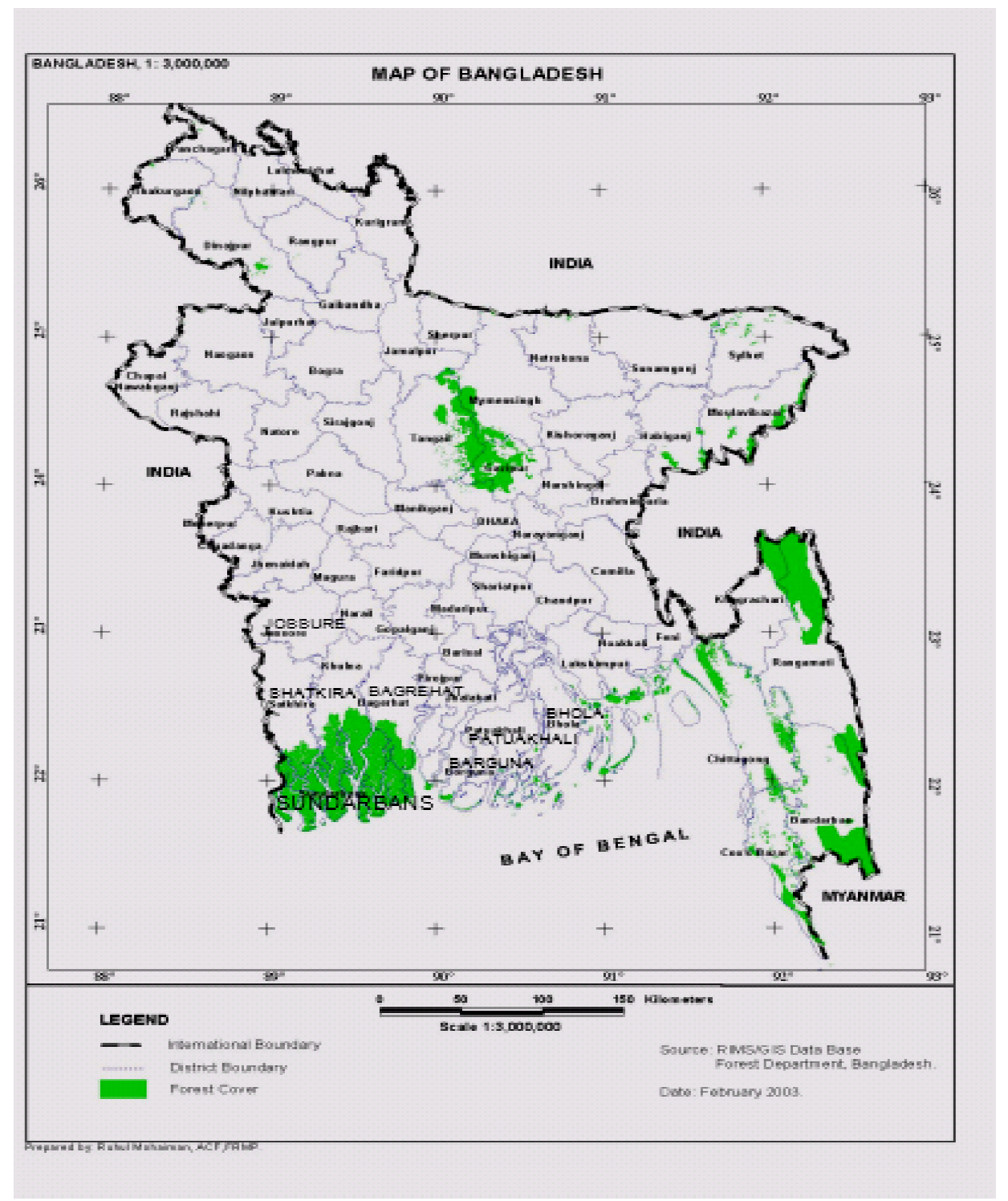

Figure 1.0. Map showing the administrative districts of Bangladesh, including the location of the Sundarbans (the shaded area in the south-west of the country).

\subsubsection{Site Selection and Location of the Study Area}

General reconnaissance of possible sites was made by visiting all the possible regional areas before categorizing and selecting plots for sampling. It was decided to sample from the Chandpai area which is the mostly human accessible and ecologically polluted area (in Figure 2.0). Three compartments from this regional area (range), namely numbers 26, 28 and 31, were selected because they were believed to represent a range of severity of top-dying disease, based on relevant maps, documents, literature, consultations with forest professionals, and surrounding peoples. The location of these compartments within the Chandpai area, and the location of this area in the wider Sundarbans is shown in Figure 2.0. Among the three compartments, compartment number 26 was selected as an area highly affected by top-dying, where most of the trees were affected severely. Compartment 26 had pronounced human activities, and also in places is undergoing rapid housing development involving extensive construction activities due to the presence nearby of the Range HQ office in Chandpai (in figure 2.0). Compartment number 28 was selected as a moderately affected area. This compartment has various human activities including boat making grounds, football-playing grounds, and cattlegrazing fields, all types of major soil erosion, a moderate amount of construction activities and the presence of communities of fishermen (figure 2.0). Compartment number 31 was chosen as being relatively little affected by top-dying disease. 


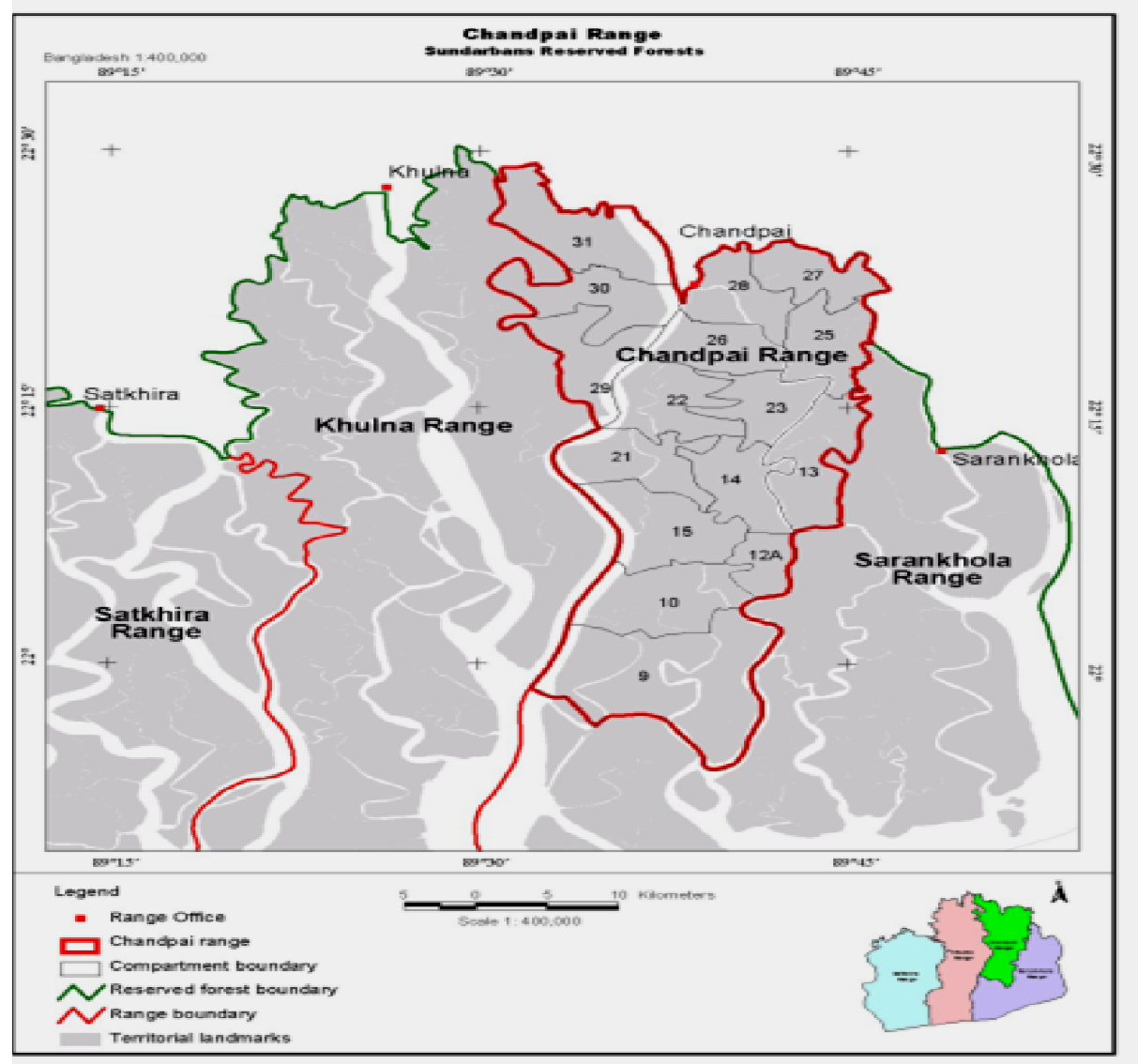

Figure 2.0. Map showing the location of the numbered compartments within the Chandpai area, and the position of this area relative to other parts of the Sundarbans in Bangladesh (darker shaded area).

Of the three chosen compartments, the nearest compartment to Mongla port is compartment 31, with comparatively modest human activities, but which nonetheless involve clear-cutting of natural vegetation, replanting with other species rather than mangrove or other native species, all types of soil erosion, and construction activities present. Within each of the three compartments, detailed observations of the regeneration and sampling of soil and water took place within three $20 \mathrm{~m} \mathrm{x} 20 \mathrm{~m}$ plots, chosen to reflect a range of top-dying intensities (High, medium and Low for that area). The sampling was conducted in a randomized block design, in that a plot was sited within a particular top-dying intensity block, but the precise location of that plot was randomized so as not to bias the detailed data collection. Thus in total nine plots were sampled, representing a range of top-dying intensities.

Intensive field data collection was made among these nine selected plots (in Figure 2.0). Observations were performed from observation towers during low and high tides, also traversing the forest floor and vegetation on foot, as well as using a speed boat, trawlers, country-boats, and a launch as required to gain access.

Fieldwork was performed in October, 2003 to March, 2004. Locations of sampling points were determined using a Global Positioning System with a precision of 5-10 m (Table1.0). For one typical plot, in compartment 31, the altitude was recorded as $4.4 \mathrm{~m}$ above sea level.

\subsubsection{Vegetation Recording Methods in the Field}

Within each of the nine $20 \mathrm{~m} \times 20 \mathrm{~m}$ plots, each adult tree was assessed for three parameters. The diameter at $1 \mathrm{~m}$ height was recorded (in $\mathrm{cm}$ ) by using a tree diametermeasuring tape or slide callipers depending on girth. The tree height to the top of the crown was determined mainly by ocular estimation but some heights were checked by using Clinometers at a set distance of $20 \mathrm{~m}$ to test the accuracy of such ocular estimations.

Finally, the status of the tree in respect of the amount of top-dying was assessed by using a four point qualitative scale of intensity, namely; not affected, little affected, moderately affected or highly affected by top-dying. This was later expressed as a semi-quantitative or rank scale of 0 to 3 respectively, so that a median rank value could be calculated and used as an index of top-dying intensity in that plot. After that, the total number of seedlings (individuals of the tree species $<1 \mathrm{~m}$ tall), and saplings (young trees $>1 \mathrm{~m}$ tall with a diameter of trunk of $<10 \mathrm{~cm}$ ), were counted within the plots. Care was taken to ensure that trees, saplings and seedlings were not counted more than once or missed in the counting process. After recording, adult trees were marked with white chalk to segregate those marked trees from other trees, seedlings 
and saplings; red paints were applied to all seedlings and saplings as they were recorded.

\subsubsection{Soil and Water Sampling Methods}

As stated above, from the three selected compartments, a total of nine plots of $20 \mathrm{~m} \mathrm{x} 20 \mathrm{~m}$ were selected. From each of these plots, seven soil samples were collected; one from the centre of the plot, four (one each) from all the corners, and two from the middle sides of the plot. Therefore a total of 63 soil samples were taken. Also nine water samples were collected from nearby rivers, creeks or channels, one from the area of each of the sampled plots. Soil samples were collected from $0-30 \mathrm{~cm}$ soil depth by using a stainless steel spatula and steel cylinder $(d=5.25 \mathrm{~cm})$, and all soil samples were kept in sealed plastic bags. Water samples were collected directly in pre-cleaned plastic-containers. Marking and labelling was performed with a detailed description of the selected sampling site on both the soilcontaining plastic bags and water containers, and preserved in portable coolers until arrival at the laboratory at Dhaka University for initial chemical analysis. This field sampling method followed the W.H.O, U.K, and E.P.A systems of standard laboratory and field sampling principles, rules and regulations. Rainfall for the area during sample collection was not notably different from the respective monthly averages for the Sundarbans of recent years; there was no heavy intensity of rainfall within one month before sampling (Awal, 2007).

Any evidence of changes was recorded, sometimes obtained through asking local people and forestry staff, or from personal observations. In particular, any soil erosion and diversion of the river's position or of new channels and creeks observed during the data collection period were recorded, as were signs of siltation changes.

\subsubsection{Questionnaire Survey of Local People}

In order to establish the views of local people about the incidence and causes of top-dying, a questionnaire was prepared for asking peoples either individually or in groups. This survey was done among people living or working in the 17 Sub-Districts of Sundarbans, making a distinction between those living within and outside of Sundarbans. They were asked whether they had seen the top-dying disease of Heritiera fomes (Sundri) in Sudarbans for a long time, either through living within the Sundarbans or through visiting Sundarbans for their daily work, for their professional work such as forestry officials, for fishing or for collecting wood as wood cutters, for seasonal honey collection, or other purposes. Groups were made up among targeted people in all locations and from all categories mentioned above, based on age, profession, and also for their sharp memory. In this way, 50 questionnaires were filled up through interview, mostly of groups and sometimes of individual people. The justification of selection of people for the questionnaire survey was that the targeted people were familiar with the top-dying problem in Sundarbans, and are related through their professions with Sundarbans directly and indirectly. The questionnaire started by establishing that the respondents were familiar with top-dying, and went on to seek their views and information on what changes they had observed and whether they had noticed possible causes. This was possible because, most of the interviewees are living within the Sundarbans for their daily activities. So, this survey was performed to receive their indigenous response and knowledge towards top dying and its present conditions, and their ideas about what leads to top-dying, as well as questions about tree regeneration and human health in Sundarbans (Awal, 2014).

\subsubsection{Statistical Analysis}

Initial statistical analysis of quantitative data, particularly of the elemental concentrations, consisted of calculation of arithmetic means, standard deviations and standard error values for each variable separately. Data on the severity of top-dying for each tree in a plot, which had been recorded as ' not affected', 'mildly affected', 'moderately affected', and 'highly affected', were converted into a four-point scale (0-3), so that they could be summed and an average (median) could be determined for each plot, thus producing an index based on ranked data. Comparisons of the strength of relationship between two variables were assessed by correlation: the Pearson's product-moment correlation coefficient where both variables were fully quantitative or the Spearman's rank correlation coefficient where the topdying index was one of the variables. In the case of the Spearman's coefficient, the probability of the outcome was determined by using the approximation to a t-statistic appropriate to these tests (Sokal and Rohlf, 1981). Occasionally, a Pearson's correlation coefficient was calculated where top-dying was one of the variables, in order to check on the extent of the difference between the rank and quantitative versions for these data. Data on frequencies of seedlings or saplings in each of the plots and compartments were tested by $\mathrm{x}^{2}$ contingency table analysis to determine whether there was an association between the selected plot type (severely, moderately or little affected by top-dying) and the three chosen compartments. A similar consideration of the different compartments as comprising one factor, and the plot type as a second, was used to test the pattern of elemental concentrations and other variables by a 2 -factor analysis of variance test with replication. This allows an assessment of the significance, not only of the two factors separately but also of the interaction term linking the two factors. It should be noted that the plot type was not a strictly controlled factor, since the three categories of top-dying intensity were relative to each other within any one compartment and might not have been exactly equivalent between the three categories; interpretation of the results from these tests therefore needs to bear this in mind. MINITAB Release 14 Statistical Software has been used for windows on CD-ROM, 2004 edition for all data analysis, both statistical and graphical, except for those produced automatically by the Excel package attached to the ICPMS. 


\section{Results}

These results are indicated as follows: if one number (all values in ppb) is given it is a mean, otherwise if a range is given they are the minimum and maximum; the number is followed by the type of material from which the data come, with no text indicating it is from sediments (the most common material reported in the literature); finally, the number in brackets indicates the numbered reference source, the sources being indicated in the legend (Table 1.0). Besides attempting to establish whether the element concentrations are elevated or not, it is valuable to explore whether there is any marked spatial (as opposed to random) variation in the concentrations found (table 1.0).

Table 1.0. Mean ( \pm 1 S.E.) and extreme heavy-metal elemental concentrations (ppb) in Sundarbans, together with comparisons with values from other published sources. An asterisk denotes a value below the limits of detection. Comparable data could not be found for all elements.

\begin{tabular}{|c|c|c|c|c|c|}
\hline \multirow[b]{2}{*}{ Element } & \multicolumn{4}{|c|}{ Values from this study } & \multirow{2}{*}{$\begin{array}{l}\text { Values reported elsewhere } \\
\text { (Data refer to sediments unless otherwise stated; number within } \\
\text { brackets indicates source in footnote) }\end{array}$} \\
\hline & Minimum & Mean & S.E. & Maximum & \\
\hline $\mathrm{Al}$ & 0.89 & 16332.44 & 854.17 & 37570.00 & $420-585\left(\right.$ soil $\left.^{1}\right) ; 8089000-46100000\left({ }^{1}\right) ; 500\left(\right.$ spring and well water, $\left.{ }^{2}\right)$ \\
\hline As & * & 4.56 & 0.24 & 10.06 & $3150-6830\left(^{7}\right)$ \\
\hline B & 0.55 & 19.20 & 2.14 & 103.80 & 2600 (spring and well water, ${ }^{2}$ ) \\
\hline $\mathrm{Ba}$ & 0.59 & 52.41 & 2.37 & 141.80 & 300 (spring and well water, $\left.{ }^{2}\right) ; 141$ (coastal soils, $\left.{ }^{5}\right)$ \\
\hline $\mathrm{Bi}$ & * & 0.40 & 0.02 & 0.74 & \\
\hline $\mathrm{Cd}$ & 0.15 & 0.55 & 0.03 & 1.62 & $\begin{array}{l}0.52-0.92\left(\text { soil }^{1}\right) ; 300-13520\left(^{1}\right) ; 43-147\left(^{4}\right) ; 0.8\left(\text { coastal soils, }{ }^{5}\right) ; 11 \\
-65\left({ }^{7}\right)\end{array}$ \\
\hline $\mathrm{Co}$ & 5.93 & 31.31 & 5.65 & 143.60 & $\begin{array}{l}0-7.9\left(\text { ocean water, }^{3}\right) ; 3800-26000\left({ }^{1}\right) ; 10.6\left(\text { coastal soils, }{ }^{5}\right) ; 5540- \\
15500\left({ }^{7}\right)\end{array}$ \\
\hline $\mathrm{Cr}$ & 3.11 & 15.72 & 3.39 & 114.90 & $\begin{array}{l}7\left(\text { spring and well water, }{ }^{2}\right) ; 1480-8560\left(\left(^{4}\right) ; 41.2\left(\text { coastal soils, }^{5}\right) ; 12.8\right. \\
\left(\text { water, }^{6}\right) ; 33200\left({ }^{6}\right) ; 19500-46100\left(\left(^{7}\right)\right.\end{array}$ \\
\hline $\mathrm{Cu}$ & 1.85 & 10.52 & 1.71 & 43.76 & $\begin{array}{l}12.2-16.6\left(\text { soil }^{1}\right) ; 12940-85600\left({ }^{1}\right) ; 22\left(\text { spring and well water, }{ }^{2}\right) ; 22- \\
37.2\left(\text { ocean water, }^{3}\right) ; 2270-14730\left({ }^{4}\right) ; 23.1\left(\text { coastal soils, }{ }^{5}\right) ; 3.8\left(\text { water, }^{6}\right) \text {; } \\
18200\left({ }^{6}\right) ; 6950-31600\left({ }^{7}\right)\end{array}$ \\
\hline $\mathrm{Fe}$ & 25.82 & 173891.10 & 9883.85 & 248200.00 & $\begin{array}{l}634-820\left(\text { soil },^{1}\right) ; 8080000-52000000\left({ }^{1}\right) ; 63\left(\text { spring and well water, }{ }^{2}\right) \\
6.2-131.5\left(\text { ocean water, }^{3}\right) ; 38.5\left(\text { water, }^{6}\right) ; 7110000\left({ }^{6}\right)\end{array}$ \\
\hline $\mathrm{Hg}$ & $*$ & 6.41 & 1.47 & 83.30 & $66-180\left(^{4}\right) ; 1.8\left(\right.$ water, $\left.{ }^{6}\right) ; 6320\left(^{6}\right)$ \\
\hline $\mathrm{Mn}$ & 0.70 & 436.80 & 14.69 & 697.00 & $\begin{array}{l}4980-438000\left({ }^{1}\right) ; 25\left(\text { spring and well water, }{ }^{2}\right) ; 1.8-40.8 \text { (ocean } \\
\left.\text { water, }{ }^{3}\right) ; 3738\left(\text { coastal soils, }{ }^{5}\right) ; 7.4\left(\text { water, }{ }^{6}\right) ; 412000\left({ }^{6}\right)\end{array}$ \\
\hline Mo & 0.20 & 1.62 & 0.46 & 26.15 & 24 (spring and well water, ${ }^{2}$ ) \\
\hline $\mathrm{Ni}$ & 7.58 & 76.08 & 18.84 & 1127.00 & $\begin{array}{l}\left.\left.10800-37400\left({ }^{1}\right) ; 3 \text { (spring and well water, }{ }^{2}\right) ; 0-12.1 \text { (ocean water, }{ }^{3}\right) \text {; } \\
24.5\left(\text { coastal soils, }{ }^{5}\right) ; 15900-44600\left(^{7}\right)\end{array}$ \\
\hline $\mathrm{Pb}$ & 0.32 & 19.30 & 0.98 & 34.19 & $\begin{array}{l}1.0-1.76\left(\text { soil }^{1}\right) ; 1460-10400\left({ }^{1}\right) ; 2\left(\text { spring and well water, }^{2}\right) ; 3440- \\
15590\left({ }^{4}\right) ; 74.0\left(\text { coastal soils, }{ }^{5}\right) ; 2.3\left(\text { water }^{6}\right) ; 12800\left({ }^{6}\right) ; 8046-15700\left({ }^{7}\right)\end{array}$ \\
\hline $\mathrm{Rb}$ & 0.18 & 36.37 & 1.65 & 76.94 & \\
\hline $\mathrm{Sb}$ & $*$ & 0.09 & 0.05 & 2.93 & $30-94\left(\left(^{7}\right)\right.$ \\
\hline Sc & $*$ & 6.05 & 0.37 & 8.98 & \\
\hline $\mathrm{Se}$ & $*$ & 0.17 & 0.05 & 1.43 & \\
\hline $\mathrm{Sn}$ & $*$ & 0.61 & 0.16 & 9.68 & $219-654\left(^{7}\right)$ \\
\hline $\mathrm{Sr}$ & 0.18 & 27.77 & 0.89 & 44.17 & 2200 (spring and well water, ${ }^{2}$ ) \\
\hline $\mathrm{Ti}$ & 4.61 & 475.39 & 26.26 & 1350.00 & $72-341\left(^{7}\right)$ \\
\hline V & 0.09 & 32.93 & 1.14 & 51.65 & 13 (spring and well water, $\left.{ }^{2}\right) ; 18500-46900\left({ }^{7}\right)$ \\
\hline $\mathrm{Y}$ & 0.03 & 6.60 & 0.34 & 16.69 & \\
\hline $\mathrm{Zn}$ & 2.30 & 73.60 & 2.23 & 112.50 & $\begin{array}{l}\left.35.0-56.2\left(\text { soil }^{1}\right) ; 120-62200\left(^{1}\right) ; 2.4-20 \text { (ocean water, }{ }^{3}\right) ; 72.5 \\
\left(\text { water, }^{6}\right) ; 43200\left({ }^{6}\right) ; 24300-76000\left(^{7}\right)\end{array}$ \\
\hline
\end{tabular}

${ }^{1}$ Balasubramanian, 1999. ${ }^{2}$ Bond, R G \& Straub, C P (eds), $1973{ }^{3}$ Braganca \& Sanzgiri, 1980. ${ }^{4}$ IUCN Reports $1987 .{ }^{5}$ McGrath \& Loveland (1992). ${ }^{6}$ Sarkar, S.K. et al. 2003 ( Premonsoon data from the mouth of the Ganga estuary near Gangasagar used). ${ }^{7}$ Zöckler, C \& Bunting, G 2006.

The results of the analyses of the basic soil and water parameters such as percentage moisture content, $\mathrm{pH}$ and EC are presented in different tables.

The present results are less than half of this (on average), suggesting that this will be adversely affecting the survivorship of the species in Sundarbans. Whether the percentage moisture content value is reflected in the amount of top-dying was tested by a Spearman's rank correlation co-efficient, and found to be significant as reported in table 2.0. 
Table 2.0. Results of various parameters of soil and water samples taken from the selected plots. Values are means of soil or water samples.

\begin{tabular}{|c|c|c|c|c|c|c|c|}
\hline Plot No. & Comp.No. & $\%$ M.C. of soil & pH of soil & EC of soil $\left(x 10^{3}\right)$ & Soil Particle size $(\mu)$ & pH of water & EC of Water \\
\hline 1 & 26 & 23.91 & 7.54 & 36.4 & 12.69 & 7.11 & 19480.0 \\
\hline 2 & 26 & 25.00 & 7.53 & 44.4 & 9.64 & 6.94 & 17580.0 \\
\hline 3 & 26 & 30.24 & 7.61 & 10.3 & 11.67 & 7.27 & 18850.0 \\
\hline 1 & 28 & 13.57 & 7.51 & 7.8 & 12.69 & 7.69 & 17480.0 \\
\hline 2 & 28 & 20.40 & 7.48 & 3.9 & 11.67 & 7.47 & 18250.0 \\
\hline 3 & 28 & 20.71 & 7.49 & 9.2 & 13.20 & 7.45 & 19140.0 \\
\hline 1 & 31 & 13.85 & 7.42 & 31.6 & 11.67 & 7.27 & 17300.0 \\
\hline 2 & 31 & 21.95 & 7.39 & 31.2 & 12.18 & 7.41 & 17790.0 \\
\hline 3 & 31 & 23.91 & 7.52 & 25.6 & 11.67 & 7.22 & 17420.0 \\
\hline
\end{tabular}

Table 3.0. General Linear Model for the Soil Nutrient parameters in Sundarbans: Analysis of Variance results, testing for the two factors of Compartment and Plot, together with their interaction. Values given are the F-results together with probability levels. (Significant results are indicated with asterisks). (Key: $p>0.05$, N.S. ; $p<0.01$, **; $p<0.001$, ***).

\begin{tabular}{|c|c|c|c|}
\hline $\begin{array}{l}\text { Soil Nutrients } \\
\text { Element }\end{array}$ & $\begin{array}{l}\text { Compartment } \\
\text { F }(2,46)\end{array}$ & $\begin{array}{l}\text { Plot } \\
\text { F }(2,46)\end{array}$ & $\begin{array}{l}\text { Interaction } \\
\text { F }(\mathbf{4 , 4 6 )}\end{array}$ \\
\hline $\begin{array}{l}\mathrm{Na} \\
\text { (Sodium) }\end{array}$ & $4.65, \mathrm{p}=0.014 * *$ & $2.14, p=0.13, \mathrm{NS}$ & $1.23, \mathrm{p}=0.31, \mathrm{NS}$ \\
\hline Exc. $\mathrm{Na}$ & $3.47, \mathrm{p}=0.039, * *$ & $0.22, p=0.80$, N.S & $1.08, \mathrm{p}=0.38, \mathrm{~N} . \mathrm{S}$ \\
\hline Soluble-Na & $3.77, \mathrm{p}=0.031 * *$ & $2.20, p=0.12$, N.S. & $0.17, p=0.95, \mathrm{NS}$ \\
\hline Soil pH & $11.67, \mathrm{p}=0.000 * * *$ & $2.71, \mathrm{p}=0.07 * *$ & $7.46, \mathrm{p}=0.000 * * *$ \\
\hline $\begin{array}{l}\text { S } \\
\text { (Sulphur) }\end{array}$ & $4.51, \mathrm{p}=0.016^{* *}$ & $0.32, p=0.73$, N.S. & $1.86, p=0.13$, N.S \\
\hline $\begin{array}{l}\mathrm{Ca} \\
\text { Calcium }\end{array}$ & $0.37, p=0.69$, N.S & $2.17, \mathrm{p}=0.13$, N.S. & $1.60, \mathrm{p}=0.19, \mathrm{~N} . \mathrm{S}$. \\
\hline $\begin{array}{l}\text { (Soluble) K } \\
\text { (Potassium) }\end{array}$ & $1.67, p=0.20$, N.S. & $0.67, p=0.52$, N.S. & $1.64, \mathrm{p}=0.18, \mathrm{~N} . \mathrm{S}$ \\
\hline $\begin{array}{l}\text { Exc. K } \\
\text { (Exchangeable - Potassium) }\end{array}$ & $5.15, \mathrm{p}=0.01 * *$ & $1.15, p=0.33$, N.S. & $0.80, \mathrm{p}=0.53, \mathrm{~N} . \mathrm{S}$ \\
\hline $\begin{array}{l}\mathrm{N} \\
\text { (Total Nitrogen) }\end{array}$ & $0.63, p=0.54$, N.S. & $0.70, p=0.50$, N.S. & $1.02, p=0.40$, N.S. \\
\hline $\begin{array}{l}\mathrm{N} \\
\text { (Soluble Nitrogen) }\end{array}$ & $0.32, \mathrm{p}=0.73$, N.S. & $0.34, p=0.72$, N.S. & $0.80, p=0.53$, N.S. \\
\hline Fe ( Iron) & $0.38, p=0.69, \mathrm{NS}$ & $1.58, \mathrm{p}=0.22, \mathrm{NS}$ & $0.74, p=0.57, \mathrm{NS}$ \\
\hline
\end{tabular}

The results from the analyses of soil parameters (Table 3) show many of the parameters tested to be markedly different in the different compartments but, except for soil $\mathrm{pH}$, not to vary significantly either in the plot or in the interaction terms. Soil $\mathrm{pH}$ was, interestingly, highly or very highly significant with both factors and the interaction (Table 2).

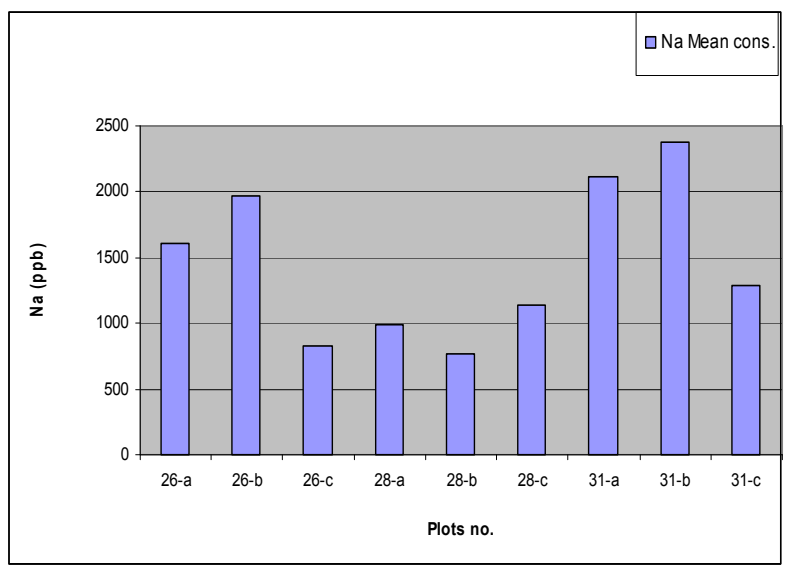

Figure 3.0. Bar chart of the average $\mathrm{Na}$ concentrations in the three compartments (26, 28 and 31) sampled in the Sundarbans, with three plots in each compartment.
It is not surprising that there are differences between the three compartments, as they had been selected in order to demonstrate a range of circumstances that might contribute to top-dying, such as nearness to human activity. As an example of the results shown in respect of this factor, Figure 3.0 shows a bar chart of the average $\mathrm{Na}$ values in the three compartments. It indicates that the compartments could be ordered in the sequence of 28,26 , and 31 with respect to this parameter, which corresponds with their location and how close they are to the coast line.

\section{Discussion}

According to Chowdhury (1984), he stated that the reduction of fresh water discharges through the Sundarbans was due to (a) the diversion of the upstream Ganges water and (b) more use of upstream water for irrigation and industrial use. Previously the rivers of the area were very active and used to lay freshly deposited silts on top soil every year where Sundri would survive well. But with the reduction in discharge of fresh water, silt carrying capacity of the river has also been reduced. Previously these areas were well drained at ebb tides but now due to change in river regime due to the Farakka barrage, the drainage patterns including flow characteristics have been changed. Consequently the trees are becoming thinner and shorter. 
Sundri (Heritiera fomes) lacks the ability to extract fresh water from salt water at even a relatively low salt concentration (Hoffman et al., 1986). Balmforth (1985), based on the report of Chaffey et al., (1985), stated that the primary cause of Sundri top-dying was the increase in soil salinity. Withdrawal of Ganges water at Farrakka because of the dam construction in 1976 was, in his opinion, one of the possible causes for the increase in salinity in the Sundarbans. Balmforth's statement regarding the causes of Sundri top-dying due to an increase in salinity was, however, not supported by his data (Awal, 2007). Moreover, the data presented by Chaffey et al., (1985), from examined soil samples collected from 20 sites including top-dying and healthy Sundri areas in the Sundarbans, are not in agreement with Balmforth's statement, nor with the conclusion of Chaffey et al., (1985) themselves. These authors had suggested that soil salinity was higher on sites affected by top-dying than on unaffected sites, and that therefore an increase in soil salinity is an important factor in the onset of top-dying. However, severely affected topdying areas are, in fact, distributed in slightly saline to nonsaline zones as presented by Chaffey et al. (1985). Thus a total of $18 \%$ of Sundri trees with d.b.h above $5 \mathrm{~cm}$ had been affected by top-dying of Sundri in Sundarbans (Chaffey et al., 1985). Only a very small number of topdying affected Sundri were present in the salt water zone (Chaffey et al., 1985); 13-15\% in moderately salt water zone, $21-24 \%$ in salt water zones and $25-47 \%$ in the fresh water zone respectively. This contrast with results of Ismail (1987), who stated that soil salinity, was higher on sites affected by top-dying than on unaffected sites, suggesting that soil salinity is an important factor in the onset of topdying.

Sattar (1977) inferred that mortality of Sundri is possibly due to edaphic changes such as heavy siltation, increase in salinity, less flooding by fresh water, and alteration in the frequency and duration of inundation. However, the decline of more salt tolerant species suggests that the cause of decline of the Sundri is not primarily due to insufficient fresh water flow during the dry season.

Christensen (1984) stated that salinity may not be a direct cause of top-dying but is an indicator of many geochemical processes that have an impact on living organisms (e.g. by affecting nutrient availability).

Hassan (1988) provided data on soil and water salinity of a number of sites in the Sundarbans. He also studied the effect of salinity of Sundri seedlings in a simulated experiment. The data on salinity was compared with those of Chaffey et al., (1985). It was observed that the top-dying did not show any consistent relationship with the salinity. Hassan (1988) reported that soil salinity in the Sundarbans varies between less than 2000 micro mhos to more than 4000 micro mhos, which rise up to about 6000 micro mohs during the lean period in April. Hassan (1988) also observed that Sundri top-dying did not show any consistent relationships with salinity. Moreover, regeneration and survival of Sundri seedlings did not show any change due to water salinity variation between the range 1,000 to 49,000 micro mhos under experimental conditions (Hassan et al., 1990). Therefore, Hassan et al., (1984) provided a detailed report on soil and salinity of the Sundarbans in relation to top-dying, regeneration and survival of Sundri. They did not observe any consistent relationships between top-dying and salinity. Regeneration and survival of Sundri seedlings also did not show any relationships to the salinity variation between 1,000 to 49,000 micro mohs under simulated conditions (Hassan, et al., 1990). It was observed by my present research that the top-dying did not show any consistent relationship with the salinity $(\mathrm{Na})$ both in soil and water (Awal, 2007), Na is not significant for top-dying disease of Sundri and does not support with Rahman statements rather it supports with Hassan (Awal, 2007). Accordingly Shell and Ross (1987) studied the $\mathrm{Na}^{+}$and $\mathrm{K}^{+}$ levels in Sundri tissues and found that: (a) the $\mathrm{Na}^{+} / \mathrm{K}^{+}$ ratios in the tissues of healthy trees appear to be related to the salinity of their local environment; (b) the average percentage of $\mathrm{Na}^{+}$and $\mathrm{K}^{+}$was not significantly different in healthy and dying Sundri trees; (c) though some link was indicated between top-dying and ionic balance in plant tissue, it was not possible to resolve the causal factor and its effect. According to Lugo and Snedaker (1974), gross primary productivity of mangroves increases with the availability of fresh water. The fresh water input to the estuary is associated with physical, chemical, geological and biological melange, fauna and flora of the estuary / coastal zone. This input tends to enrich the sites (Snedaker et al., 1977). Imam (1982) noted that a system analysis and simulated studies on the ecology of mangrove forests in Florida, USA, had demonstrated that terrestrial water plays a vital role in the development of mangrove biomass, which in turn reflects the gross photosynthesis. It has been construed that both mangrove zonation and vigor are functions of nutrient availability rather than salinity alone.

On the basis of the above findings Sheil and Ross (1987), concluded that these observations are compatible with a pathogenic cause of top-dying as forwarded by Rahman et al., (1983). This means that in their opinion salinity is not the causal factor for the top-dying (Awal, 2007).More recent research on the association between salinity and topdying of Hetiera fomes has concluded that it is not the causal factor previously thought (Awal, 2007). Hassan et al. (1990) suggested that there is no relationship between salinity and top-dying of Sundri, and data of Rahaman et al. (2003), where soil salinity was estimated in terms of the level of sodium $(\mathrm{Na})$ and electrical conductivity, revealed that there is no significant variation in the mean value of $\mathrm{Na}$ and EC in soil of the Sundarbans. According to Gupta et al. (1986), reporting on the salt tolerance of some tree species at the seedling stage, the salinity ranges which prevail in the Sundarbans are tolerable even to some mesophytes such as Eucalyptus camaldulensis and Acacia nilotica. This observation contradicts with the inference that a species such as Sundri should be seriously affected by the salinity observed. Moreover, without a governing 
cause top-dying could not merely increase with time, as suggested by Chaffey et al. (1985), indicating that salinity alone can not be the cause of top-dying of Sundri.

\section{Conclusion}

Besides the heavy-metal concentrations in the soil, the result presented in this research result found that there was not a significant relationship between soluble and exchangeable $\mathrm{Na}$, soluble $\mathrm{K}, \mathrm{Ca}, \mathrm{Mn}$, and $\mathrm{CEC}$, in either soil or water, and $\mathrm{pH}$ of water, with the amount of topdying, or with parameters of tree growth (Awal, 2007). However, there was a negative correlation between the concentration of exchangeable $\mathrm{K}$ and the average tree diameter (Awal, 2007).

It is natural to have salts present in any soil and salinity refers not to the presence of salt but rather to the presence of too much salt. Some halophyte plants can grow on soils with high salt content e.g. mangrove species particularly Ceriops decandra (Goran tree) in Sundarban. The common terrestrial plant systems are composed of "mesophytes", plants adapted to a moderate supply of water. In more saline situations, soil salt absorbed by plants may accumulate to toxic levels, leading to the death of cells and tissues; the leaf cell will die, if chloride concentrations reach toxic levels ( $\mathrm{Na}>0.25-0.50 \%$ and / or chloride above $0.5-1.0 \%$ (Leece, 1984). It has been found that salinity concentration accelerates the rate of catabolism by decreasing the metabolism of Sundri (Islam, 2003), but it has not been established whether this is harmful to the tree.

The present results include what are believed to be the first use of modern analytical equipments, particularly the ICP-MS, to analyze chemical concentration in soils in the Sundarbans. In the light of the results obtained, it is clear that further work needs to be done on the heavy metal concentrations and their impact on top-dying in the Sundarbans. This should probably follow three lines of inquiry : (1) to investigate more extensively the concentrations of the heavy-metals across the Sundarbans, particularly to assess whether contamination is coming from sites such as Mongla port, and also to determine whether concentrations are ever notably higher than those found here, which not only could be contributing to topdying, but also to human health problems; (2) to investigate more intensively the role of the elements particularly singled out earlier in this chapter in order to confirm that they do indeed relate to top-dying; (3) and to investigate by means of experimental additions of selected elements whether this leads to changes of top-dying in the manner predicted in this chapter. Although there were only a few individual chemical elements which showed significant correlations with the amount of top-dying table.3, there was evidence of elevated heavy-metal concentrations of almost 14 elements out of 32 tested elements in the Sundarbans, which are likely to contribute to the increase in top-dying observed table 1. There were also significant differences between different areas in the Sundarbans, and evidence of water supply problems to the system Table 2. Therefore, it is concluded that several factors are responsible for this increase in top-dying, rather than one specific factor only (table 1). Therefore, salinity alone can not be the cause of top-dying of Sundri (Awal, 2007).

\section{Acknowledgement}

My research work was supported financially by the Peoples' Republic of Bangladesh and the Asian Development Bank (ADB), whom I thank. Particular thanks are due to the ADB head office, Manila for their support and help. I thank sincerely Dr. W.G.H. Hale (Principal Supervisor), University of Bradford, UK, Professor Mike Ashmore (Technical Supervisor), University of York, UK and Dr. P.J. Hogarth for their advice and comments on the work; Dr. Ben Stern and the staff at the Analytical Centre, Bradford, for their help with the ICPMS analyses; Professor Sirajul Hoque, Mustafa (lab Technician)and staff at Dhaka University for providing facilities; and staff of the Forestry Service, Bangladesh Government, for field assistance. Moreover I indebted to my beloved parents Munshi Aowlad Hossain (Father: Teacher and Landlord as well as blossom friend of poor), Mrs. Ashrafunness( Mother: born Literate and Socialist, pious and friend of poor and distress), my venerated fore-fathers:Abadat Biswas (Mighty-Landlord), Golam-Rabbani-Biswas(Mighty-Landlord) my esteemed grandfathers (Munshi Bellal Hossain Biswas (LearnedLiterate-Landlord), Md. Ataher (Lawyer and Powerful Jotdar and Landlord), my respected grand-mothers: Rohima Khatun (pious \& friend of poor), and Alimoonnessa (social, pious and friend of poor and distress), Dr. Shajahan Kabir(Nephew), my beloved wife (Dr. Shahanaj Khatun), my beloved son (Munshi Tasneem Redowan), my beloved daughter (Marwa Ashra), my beloved brothers: Munshi Abul Kalam Azad (Officer in BAF), and Munshi Abdus Salam (Program Officer in UNDP), Munshi Abdul Rouf (Businessman), Motiar Rahman (Local Leader and social worker), and my beloved 6 sisters (Layla Anjumand Banu (Chandu), Akter Rashida Banu (Turi), Saleha Pervin (Lili), Azmeri Ferdowsi (Dolly), Jannatul Ferdowsi (Polly) and my beloved youngest sister Bedowra Ferdowsi (Jolly), Chandona, Sultana, Rono, Chapa, Loti, Urfa, Alta, Joytoon, my respected only uncle Munshi Abdur Razzak (Teacher and Jotder as well as blossom Friend of poor people),NoorJahan (unty), Kolimuddin Biswas(Aunt), my venerated maternal uncles: Anowarul Azim (Director of Family Planning), Amirul Azim (First Class-Magistrate and UNO), Aftabul Azim (Banker), Azizul Azim (Influential Leader and Govt.-Officer in Land Department), Anisul Azim (Social Leader and influentialBusinessman), Aminul Azim(Dramatist), my respected Khalas (Khuki, Bulbul), as well as all family members for their inspiration and help. 


\section{References}

[1] Awal, M.A. (2007). Analysis of possible environmental factors causing top-dying in mangrove forest trees in the Sundarbans in Bangladesh. PhD thesis, University of Bradford.

[2] Awal, M.A., Hale, W.H.G. \& Stern, B. (2009). Trace element concentrations in mangrove sediments in the Sundarbans, Bangladesh. Marine Pollution Bulletin, 58(12), 1944-1948.

[3] Awal, M.A. (2014). "Correlation between the chemical composition of the surface sediment and water in the mangrove forest of the Sundarbans, Bangladesh, and the regeneration, growth and dieback of the forest trees and people health"..Journal of Science Innovation; 2014. 2(2): pp.11-21.Science Publishing Group, USA; May 20th, 2014(2):11-21;doi: 10.11648/j/si.20140202.11.

[4] Anonymous, 1972. Ecology. In: Penyata tahunan perhutanan di-Malaysia Barat 1968. Government Printer, Kuala Lumpur.: volume 6.1.

[5] Balmforth, E. B. 1985. Observation on Sundri top dyingdescriptive Sampling. In the Sundarbans reserved forest. Draft Working Paper, UNDP/FAO Project BGD/77/017, and Dhaka.32 pp.

[6] Banik, H. 2000. Bangladesh Sundarbans. Hitutumi Book House and Publishers. TalpukurPar, Comilla, (in Bangla), Bangladesh.

[7] Beeftink, W. G. 1965. Dezout vegetative van ZWNederland Beschouwd in Europees verband. (Saltmarsh communities of the SW Netherlands in relation to the European halo-phytic vegetation) Meded. Landbouwhogesch. Wageningen, 65(1): 2-166.

[8] Beeftink, W.G. 1966. Vegetation and habitat of the salt marshes and beach plains in the south-western part of the Netherlands. Wentia, 15: 83-108.

[9] BFRI, 1990-95. Annual Research Report. Silviculture Genetics Division. Bangladesh Forest Research Institute (BFRI), Chittagong, Bangladesh.

[10] Bhuyan, A. A. 1994. Draft final report of the soil scientist. FAO / UNDP Project-Integrated Resource development of the Sundarbans Reserved Forest, Khulna, Bangladesh, 124 pp.

[11] Blasco, F. 1975. Mangroves in India. French Institute of Pondicherry. Trav. 14: 1-80.

[12] Chaffey, D. R; Miller, F.R; Sandom, J. H. 1985. A forest inventory of the Sundarbans, Bangladesh, Main report, Project Report No.140, 196 pp; Overseas Development Administration, London, U.K:195-196.

[13] Chapman, V. J. 1960. Salt Deserts of the World. Hill, London, pp. 391-392.

[14] Chapman, V. J. 1977. Ecosystem of the World, Wet Coastal Ecosystems, Vol-1, Oxford-New York, Elsevier Scientific Publishing Co, 1977: 79-80.

[15] Chowdhury, A.M. 1984. Integrated Development of the
Sundarbans, Bangladesh: Silvicultural Aspects of the Sundarbans. FAO Report No / TCP/ BGD/ 2309 (Mf), W / R003.

[16] Chowdhury, M. I. 1984. Morphological, hydrological and ecological aspects of the Sundarbans. FAO report N0. FO: TCP/BGD/2309(Mf) W/R0027, 32 P.

[17] Christensen, B. 1984. Integrated development of the Sundarbans, Bangladesh: Ecological aspects of the Sundarbans. Reported prepared for the Government of Bangladesh. FAO report no. FO: TCP/ BGD/2309(MF) W/ R0030.

[18] Curtis, S.J. 1933. Working Plan for the forests of the Sundarbans Division, for the period from $1^{\text {st }}$ April 1931 to $31^{\text {st }}$ March, 1951, Vol.1, 175 p. Bengal government press, Calcutta, India.

[19] Daiber, F.C. 1974. Salt marsh plants and future coastal salt marshes in relation to animals. In: R.J. Reimold and W.H. Queen (Editors), Ecology of Halophytes. Academic Press, New York, N.Y:475-510.

[20] Davis, J. H. 1940. Ecology and geologic role of mangroves in Florida. Carengie Institution, Washington, Publication, No. 517: 303-412.

[21] Davis, L.V. and Gray, I.E. 1966. Zonal and Seasonal distribution of insects in North Carolina salt marshes. Ecological Monographs, 30(3) 275-295.

[22] Government of Bangladesh, (1993). Forestry Master Plan: Executive Summary. Asian Development Bank, UNDP/FAOBGD/88/025, Forest Department, Government of Bangladesh, Dhaka.31p.

[23] Gupta, G. N; Prasad, D. S; Manivachakam, P. 1986. Salt tolerance of some tree species at seedling stage. Indian Forester, 112(2): 101-113

[24] Hassan, M. M. 1988. Soil and Salinity of the Sundarbans in relation to top dying, regeneration and survival of Sundri. UPR of Bangladesh Forest Research Institute, Chittagong: 9.

[25] Hassan, M. M.; Mazumder, A. H.; Islam, A. T. M. N. and Hossain, A.T. M. E. 1990. Soil, hydrology and salinity of Sundarbans in relation to top dying, regeneration and survival of Sundri (Heritiera fomes) trees. In: Rahaman, M. A.; Khandakar, K.; Ahmed, F.U. and Ali, M.O. (Eds.). Proceedings of the Seminar on Top Dying of Sundri (Heritiera fomes) Trees. Bangladesh Agricultural Research Council, Dhaka: 1- 11.

[26] Howlader, A. S. 1973. Report on the Preliminary investigation of Probable causes of Top-Dying, Regeneration and Survival of Sundri. Unpublished Report, BFRI, Chittagong, 9 pp.

[27] Imam, S. A. 1982. The Sundarbans and its future. In: proceedings of the Second Bangladesh National Conference on Forestry, Dhaka, Bangladesh, p.19-24.

[28] Ismail, M. 1987. Significance of Bangladesh estuarine and mangrove ecology. Proceeding $9^{\text {th }}$ International Symposium on Tropical Ecology and international Conference on Rehabilitation of Disturbed Ecosystems: Global Issue, December 11-16. International Society for Tropical Ecology. Department of Botany, Banaras hindu University, Varanasi, India. 
[29] Karim, A. 1988. Environmental factors and the distribution of mangroves in Sundarbans, Unpublished report, Calcutta, India: $\mathrm{p} 220$.

[30] Leece, D. R. 1984. Effects of Salinity and Pesticides on Terrestrial Plant Systems, Pollution and Plants, (Eds.) D.M.H. Cheng and C.D. Field (1984):23-42.

[31] Lugo, A.E. and S. C. Snedaker, 1974. The ecology of mangroves. Annual Review of Ecology and Systematics, 5: 39-64.

[32] Macnae, W. 1968. A general account of the fauna and flora of mangrove swamps and forests in the Indo-West Pacific region. Advance Marine Biology, 6: 73-270.

[33] McMillan, C.1975. Interactions of soil texture with salinity tolerances of Avicennia germinans (L.) Lam. And Laguncularia racemosa (L) Gaertn from North America. In: Proceedings of the International Symposium on Biology and Management of Mangroves, (eds.) G.E. Walsha, S.C. Snedaker and H.J. Teas, Volume 2: 561-68.Gainesville, University of Florida, U.S.A.

[34] Prain, D. 1903. Flora of the Sundarban. Records of the Botanical Survey of India. Periodical Expert Book Agency, Delhi.pp.231-370.

[35] Rahman, M.A. 2003. Genetic Approach to mitigate the top Dying Problem of Heritiera fomes in the Mangrove Forests, Khulna University, Bangladesh, 87pp.

[36] Rahman, M.A. 2003. Mid-term Report on Top Dying of Sundri (Heritiera fomes) and Its Management in the Sundarbans Biodiversity Conservation Project, Khulna.109pp.

[37] Ross and Shell, 1987. Na and K level in Sundri tissue, Cambridge University press, London.
[38] Sahgal, B. 1991. Sanctuary; Asia. The Complete Ecology \& Wildlife. Bi-Monthly, Volume, XI. No. 2. 1991.

[39] Sattar, M. A. 1977. Sundri mortality in Sundarbans. In: Proceedings of the First Bangladesh National Conference on Forestry, Dhaka: 12-100.

[40] Shafi, M. 1982. Adverse effects of Farakka on the forests of south- west region of Bangladesh (Sundarbans). Proceedings of the Second Bangladesh National Conference on Forestry, Dhaka, Bangladesh: 30-45.

[41] Shafi, M.1982. Artificial regeneration of Keora (Sonneratia Appetalla) in Bangladesh. Proceedings of the Bangladesh second national conference on forestry, Dhaka: 136-139.

[42] Siddiqi, N. A; Islam, M. R; Khan, M.A.S. and Shahidullah, M. (1993). Mangrove nurseries in Bangladesh. Mangrove ecosystems occasional papers. International Society for Mangrove Ecosystems, Japan: 1-14.

[43] Snedaker, S.C. 1977. General Ecology and Resource Utilization Potential of the Sundarbans, FAO Report No.Fo:TCP/BGD/2309 (MF) W/R, 28 prepared for the Government of Bangladesh, Dhaka: 31.

[44] Sokal, R.R. and Rohlf, F.J. (1981). Biometry. San Francisco, w.H. Freeman.

[45] UN-ESCAP, 1987. Final Report: Volume 2. Coastal environment management plan for Bangladesh. Bangkok, Thailand.

[46] UN-ESCAP, 1988. Coastal environment management plan for Bangladesh. Bangkok, Thailand: 7-34.

[47] UNESCO, 1997. Convention Concerning the Protection of the World Cultural and Natural Heritage, France, Paris. 